\title{
Prediction of Stem Volume, Biomass and Carbon Using Age for Eucalyptus grandis in Nuwara Eliya and Badulla Districts
}

\author{
Subasinghe S.M.C.U.P.* \\ Department of Forestry and Environmental Science, Faculty of Applied Scienses, University of Sri \\ Jayewardenepura, Nugegoda, Sri Lanka \\ *upul.forestry@gmail.com
}

\begin{abstract}
Forest trees act as carbon sinks and the main stem of the trees contribute most to the carbon storage. Since Eucalyptus grandis has been extensively planted by both government and private sectors in the upcountry wet zone of Sri Lanka, this study attempted to predict the volume, biomass and carbon content of the main stem of this species with age. In order to obtain a wider geographical coverage in data collection, 30 even-aged Eucalyptus grandis monoculture plantations were selected from Nuwara Eliya and Badulla Forest Divisions. Age of those plantations varied from 7 to 40 years. Radom sampling of 0.02 ha plot size was used for data collection. Diameter at breast height and total height were measured from the sampled trees and a core sample was obtained from the stem for the determination of biomass and carbon amounts. Stem volume was estimated by using the model $v=0.3648(\mathrm{~g} * \mathrm{~h})$ built by Subasinghe in 2001 for the same species. Stem biomass and carbon amounts of the stem were estimated by converting biomass and carbon contents of the extracted core samples of known volumes. Walkley-Black method was used for carbon content determination and the tree age was obtained from the plantation records available in the Sri Lanka Forest Department. Non-linear regression models were then built by using GENSTAT software to predict the selected variables using tree age. Both exponential and logistic curves were fitted to the data and model evaluation was done by the $\mathrm{R}^{2}$ values and the fitted line plots.
\end{abstract}

According to the results, the stem biomass of the average tree varied from $110.8 \mathrm{~kg}$ at age 7 to $1,095.4$ at age 40 . Stem carbon content varied from $68.7 \mathrm{~kg}$ at age 7 to $679.4 \mathrm{~kg}$ at age 40 . When compared with the exponential models, logistic models showed poor performances and the finally selected models for predicting $\mathrm{dbh}$, height and stem volume with age were $d b h=17.83 \times 1.028^{\text {age }}, h=20.09 \times 1.019^{\text {age }}, v=0.264 \times 1.066^{\text {age }}$. The $\mathrm{R}^{2}$ values for the selected models were $79.1 \%, 84.0 \%$ and $80.1 \%$ respectively. The selected stem biomass and stem carbon prediction models were $B M_{\text {stem }}=108.3 \times 1.059^{\text {age }}, C_{\text {stem }}=69.9 \times 1.059^{\text {age }}$ and those two models had $\mathrm{R}^{2}$ of $78.7 \%$ and $82.1 \%$ respectively. The fitted line plots too indicate very good fits of all the selected models.

Keywords: Eucalyptus grandis, Stem volume, Biomass, Carbon, Growth prediction 